\title{
Adhesion of L929 Mouse Fibroblast Cells on Poly(Styrene)/Poly(Methyl Methacrylate) Films
}

\author{
Adriana de Melo, ${ }^{a}$ Ângela Cristina Bet,${ }^{b}$ Jamil Assreuy, ${ }^{b}$ Nito Angelo Debacher ${ }^{a}$ and Valdir Soldi ${ }^{* a}$ \\ ${ }^{a}$ Departamento de Química and ${ }^{b}$ Departamento de Farmacologia, \\ Universidade Federal de Santa Catarina, 88040-900 Florianópolis-SC, Brazil
}

\begin{abstract}
Filmes de poli(estireno) (PS), poli(metacrilato de metila) (PMMA), blenda de PS/PMMA $(1: 1)$ e copolímero PS- $b$-PMMA foram preparados e avaliados quanto à adesão celular usando fibroblastos de camundongos L929. Embora todos os filmes poliméricos tenham se mostrado bons substratos para o crescimento e proliferação celular, estes processos foram levemente favorecidos na blenda PS:PMMA. O número e a morfologia foram idênticos para cultura de células nos filmes e na lamínula de vidro ou na placa de plástico. A característica química dos filmes poliméricos é adequada para suportar o ataque e proliferação das células, sugerindo que esses filmes são bons candidatos para usos biomédicos.
\end{abstract}

Films of pure poly(styrene) (PS), pure poly(methyl methacrylate) (PMMA), a 1:1 PS/PMMA blend and a PS- $b$-PMMA copolymer, were prepared and tested for cell adhesion using L929 mouse fibroblasts. All polymer films were found to be good substrates for cell adhesion and proliferation, and both processes were slightly favored on films of the 1:1 PS/PMMA blend. The same results were obtained in terms of cell number and morphology for cells cultured on films, glass coverslips or plastic plates. The chemical characteristics of polymer films make them suitable supports for cell attachment and proliferation, indicating that these films are good candidates for biomedical uses.

Keywords: poly(styrene), poly(methyl metacrylate), block copolymer, cell adhesion, cytotoxicity

\section{Introduction}

Biomaterials are one of the most productive research areas in materials science. As a result, a great diversity of new classes of materials has been created. ${ }^{1,2}$ These new materials have different compositions and include metal alloys, advanced ceramics, polymers and composites. ${ }^{1-10}$ The interaction of cells with polymers plays an important role in biotechnological and biomedical applications. ${ }^{2}$ Biomedical uses for synthetic polymers include vascular replacement systems, orthopedic devices and drug delivery systems. The physicochemical and mechanical characteristics of such polymers are generally designed to be appropriate for their proposed function. ${ }^{4}$

In vitro cell culture assays are commonly used for biocompatibility evaluations. ${ }^{11,12}$ The advantages of cell cultures include low price, relatively well-controlled variables and quantitative results in short time periods. Finally, they are considered a very sensitive means of biocompatibility testing.

\footnotetext{
*e-mail: vsoldi@qmc.ufsc.br
}

Commonly, cell affinity includes two important factors: cell attachment and cell growth. Cell attachment belongs to the first phase of cell/material interactions and the quality of this phase will influence the cell capacity to proliferate and to differentiate itself on contact with the material. ${ }^{13,14}$ Factors such as the hydrophilicity/ hydrophobicity ${ }^{15}$ and surface energy ${ }^{16}$ and charge ${ }^{17,18}$ of the material greatly influence the cell attachment and growth. In addition, surface roughness would be enhanced by adsorption of the proteins in the culture medium to form biofilms, ${ }^{19}$ which could mediate the cell adhesion. Recently, Tsai et al. ${ }^{20}$ studied the adhesion of NIH 3T3 murine fibroblasts on oxidized polystyrene (PS) surfaces modified with random copolymers of PS and poly(methyl methacrylate). The authors suggested that the adhesion of the fibroblast cells was more favorable on the PS than on the copolymer surface.

In the present study, polymeric films of PS, PMMA, 1:1 PS/PMMA blends and a PS- $b$-PMMA block copolymer were prepared and characterized. The biocompatibility of the polymeric films was assessed by studying the cell attachment and proliferation of L929 mouse fibroblasts. 


\section{Experimental}

Poly(styrene) (PS), Mw $=300500 \mathrm{~g} \mathrm{~mol}^{-1}$, and poly(methyl methacrylate) (PMMA), Mw $=139595 \mathrm{~g} \mathrm{~mol}^{-1}$, were obtained from Aldrich Chemical Co. (St. Louis, USA). PS- $b$-PMMA (Mw $\left.=780000 \mathrm{~g} \mathrm{~mol}^{-1}\right)$ was kindly supplied by Dr. Redouane Borsali (CERMAV, Grenoble, Fr), and chloroform $\left(\mathrm{CHCl}_{3}\right)$ was obtained from Nuclear (São Paulo, Brazil). All materials were used without further purification. L929 mouse fibroblasts were obtained from American Type Culture Collection (Manassas, USA).

Films were prepared by dissolving the polymers in $\mathrm{CHCl}_{3}(2 \% \mathrm{~m} / \mathrm{v})$ in a closed flask under magnetic stirring for $24 \mathrm{~h}$ at room temperature followed by solvent evaporation (casting method).

DSC analysis of the films was carried out in a DSC 50 instrument (Shimadzu, Kyoto, Japan). Measurements were carried out from $50^{\circ} \mathrm{C}$ to $280^{\circ} \mathrm{C}$ in nitrogen atmosphere at a flow rate of $50 \mathrm{~mL} \mathrm{~min}^{-1}$, with a heating rate of $10^{\circ} \mathrm{C} \mathrm{min}^{-1}$.

The hydrophobic/hydrophilic properties of the film surface were assessed by means of static contact angle measurements using the sessile drop method with ultra-pure deionized water $\left(\mathrm{H}_{2} \mathrm{O}\right)$. Five measurements were carried out for each sample.

Micrographs of the films were obtained using a XL 50 microscope (Phillips, The Netherlands), equipped with a tungsten filament as the electron source. Samples were coated with a thin layer of gold using a D2 diode sputtering system.

Each of the polymeric films was cut into circular disks, soaked in $70 \% \mathrm{v} / \mathrm{v}$ ethanol, placed under UV light for $30 \mathrm{~min}$ for sterilization, and extensively washed with sterile phosphate-buffered saline (PBS). For the experiments, cells were detached with trypsin, counted in a hemacytometer and seeded at a density of 50000 cells/well. Two types of control were used: cells seeded directly onto the well of the plastic plate or on top of a glass coverslip lying on the bottom of the well. After a $24 \mathrm{~h}$ incubation period, cell morphology was assessed by optical inverted microscopy and SEM.

\section{Results and Discussion}

\section{Characterization of the films}

The films were first characterized in terms of the thermal behavior, morphology and hydrophobicity.

Single glass transition temperatures $(\mathrm{Tg})$ were observed for PS and PMMA (at $90{ }^{\circ} \mathrm{C}$ and $101^{\circ} \mathrm{C}$, respectively), and these values are similar to those reported in the literature. ${ }^{21,22}$ Two distinct $\mathrm{Tg}$ values were observed for the 1:1 blend (82, PS and $98^{\circ} \mathrm{C}$, PMMA), suggesting that the interaction between PS and PMMA is purely physical rather than chemical, therefore indicating immiscibility between the two polymers. In the case of block copolymers, the Tg of each segment should be observed individually. The first $\mathrm{T}_{\mathrm{g}}$ value corresponds to the PS block $\left(101^{\circ} \mathrm{C}\right)$, and the second to the PMMA block $\left(122^{\circ} \mathrm{C}\right)$. The $\mathrm{T}_{\mathrm{g}}\left(122^{\circ} \mathrm{C}\right)$ was similar to the value determined by Yu et al. ${ }^{23}$ for syndiotactic PMMA $\left(125{ }^{\circ} \mathrm{C}\right)$, suggesting that the PMMA tacticity (in the copolymer) was not the same as that observed for PMMA when pure or as a component in the blend. The side chain of isotactic PMMA is characterized by high frequency in the rotation (high mobility) which is associated with a $T_{g}$ lower than the syndiotactic value. The syndiotactic conformation of PMMA in the copolymer was confirmed by infrared spectroscopy (spectra not showed) by comparing the absorption frequencies of the bands at $1270 \mathrm{~cm}^{-1}$ and $1260 \mathrm{~cm}^{-1}$ which are sensitive to syndiotactic and isotactic PMMA, respectively. ${ }^{24}$ Besides the higher $\mathrm{T}_{\mathrm{g}}$ value, the PMMA in the copolymer also has a higher absorption frequency at $1270 \mathrm{~cm}^{-1}$ than the isotactic PMMA.

The water contact angles of the PS, 1:1 PS/PMMA, PMMA and PS- $b$-PMMA films were 95. $0^{\circ} \pm 0.3$, $80.8^{\circ} \pm 0.5,86.1^{\circ} \pm 0.3$ and $82.8^{\circ} \pm 1.8$, respectively. Results showed that the PS film surface has the highest hydrophobicity and the film obtained from the 1:1 PS/ PMMA blend is the most hydrophilic. The contact angles for the systems 1:1 PS/PMMA, PMMA and PS- $b$-PMMA ranged from $80-86^{\circ}$, i.e. the values were very close due to the presence of PMMA. The lower angle determined for the copolymer, in relation to pure PMMA, can be attributed to the presence of more PMMA (higher molecular weight) than PS in the copolymer and also to the syndiotactic conformation discussed above.

In a previous study, ${ }^{25}$ hydrophilicity was found to be an important factor in defining the cell affinity for polymeric membranes. Based on the results obtained for the contact angles, the 1:1 blend has the most hydrophilic surface when compared with the other polymeric films tested, and, as will be discussed later, a more efficient cell adhesion was observed for this blend.

The surface micrographs (not shown) for the pure polymer films show characteristically dense systems, as well as the absence of domains and roughness. In the 1:1 blend micrograph, the presence of domains was observed, as would be expected for immiscible blends, which corroborates the data obtained using DSC. In the block copolymer film micrograph, discrete roughness was observed.

\section{Cell adhesion analysis}

As can be seen in Figure 1, L929 cells attached to and spread over the surface of all polymeric films and the results 

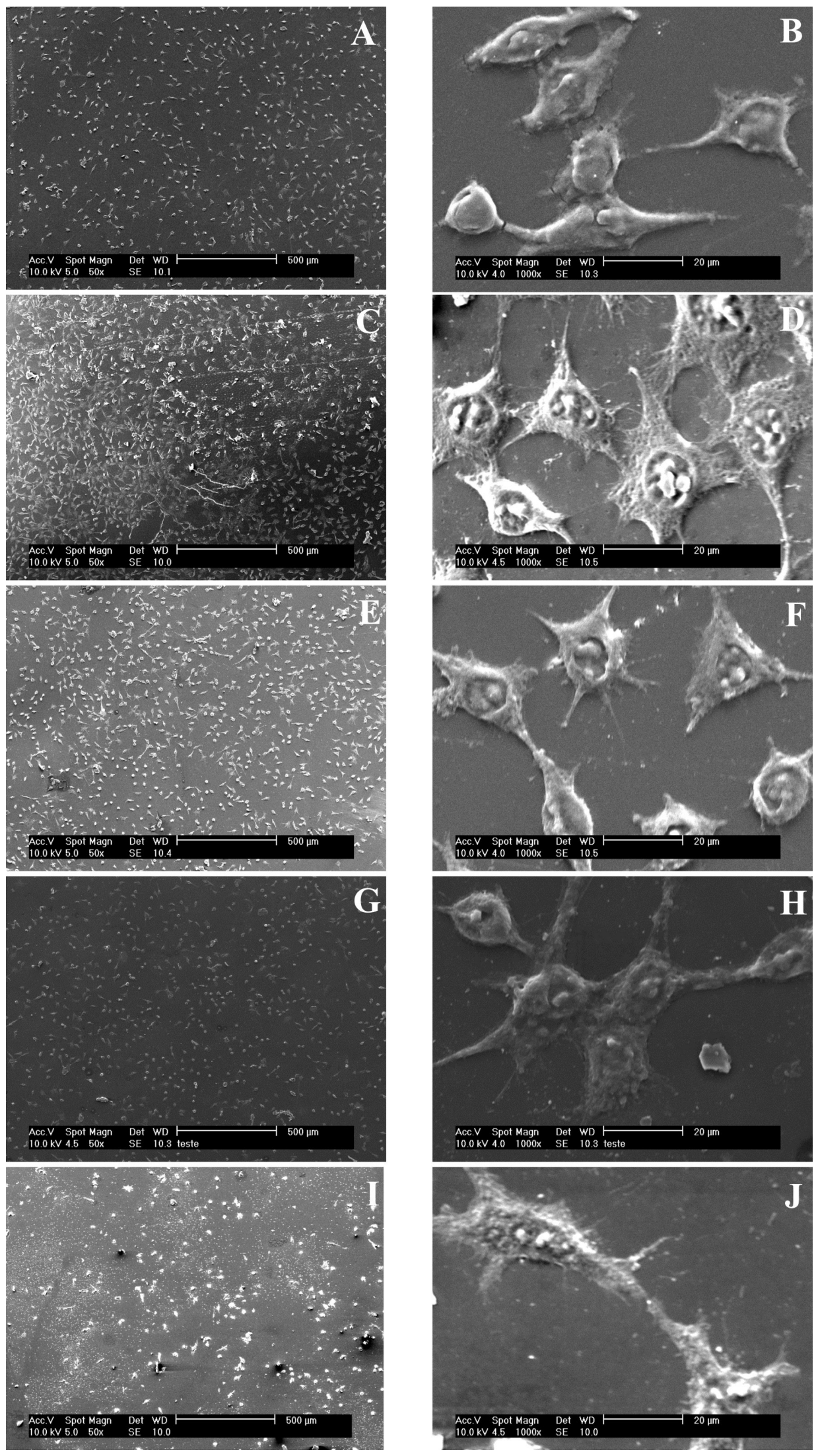

Figure 1. SEM pictures of L929 fibroblasts on the surface of pure PS film (A and B), PS/PMMA blend film (1:1) (C and D), pure PMMA film (E and F), PS-b-PMMA copolymer film ( $\mathrm{G}$ and $\mathrm{H}$ ) and control (I and J) after 24 hours of cell culture. $50 \mathrm{x}$ magnification (A, C, E, G and I) and $1000 \mathrm{x}$ magnification (B, D, F, H and J). 
for cell number and morphology did not differ from those of the control wells. Several attachment processes can be seen in all images, verifying that the L929 cells adhered strongly to the polymeric films.

The results of the quantitative analysis revealed that there were no significant differences regarding the number of cells adherent to the polymeric films when compared to the control (Figures 1I and 1J), although it can be seen that cells seeded onto 1:1 film exhibited a greater number of attachment processes.

On the pure polymer films (Figures $1 \mathrm{~B}$ and $1 \mathrm{~F}$ ) and on the block copolymer film (Figure 1H), fewer cells were seen when compared to the 1:1 blend film (Figure 1D). In addition, on the pure polymer films the cells are round or slightly stretched whereas on the blend, they have a starlike morphology.

Our results are similar to those described by Tsai et al. ${ }^{20}$ considering the PS surface. However, as observed in our study, cell adhesion was slightly favored in the 1:1 PS/ PMMA blend, when compared to PS and the PS- $b$-PMMA copolymer. According to Yang et al. ${ }^{25}$ hydrophilicity is a relevant factor in defining cell adhesion. Polymeric films with moderate hydrophilicity are more efficient at promoting cell adhesion, which may explain the greater adherence and the morphological variety observed for the cells on the 1:1 blend film. The contact angle for this specific surface was found to be lower than for the other films studied, which reveals the 1:1 blend film to be that with the most hydrophilic character. Hydrophobicity can also explain the slight adherence observed on the PS film (Figure 1B), as suggested by the contact angle experiments.

According to Rogero et al.,${ }^{26}$ an in vitro cytotoxicity assay should be the first method used to check the biocompatibility of any material to be used in biomedical devices. All films allowed cells to adhere and proliferate in a manner indistinguishable from control groups. Since the general morphology and the adherence and proliferation patterns were identical to the control, we decided not to conduct systematic cytotoxicity assays. None of the films studied showed toxic effects (numerically represented as a ' 0 ' level of toxicity). Taking into consideration the standard deviation, very similar results for the number of cells were obtained for the films as compared to the negative control (170 cells / field).

The films described herein may be useful in applications such as burned skin coverage as they would prevent water loss by perspiration and would allow fibroblast attachment and proliferation. However, before their application more studies with other cell types are necessary to ensure their safe use.
In summary, the films studied presented characteristics that are highly desirable in biomaterials for biomedical applications. All films are suitable for promoting cell adhesion and proliferation, without the need for any surface modification.

It seems advantageous to use the 1:1 blend in future experiments, since this material has an additional benefit, its cost-effectiveness. In vivo cytotoxicity and cell adhesion tests are necessary to establish a more precise and direct evaluation of the advantages and disadvantages of PS/ PMMA systems.

\section{Acknowledgments}

Financial support was provided by CNPq, FAPESC and UFSC. The technical assistance of Mrs. Adriane Madeira is gratefully acknowledged.

\section{References}

1. He, B.; Wan, Y.; Bei, J.; Wang, S.; Biomaterials 2004, 25, 5239.

2. Smolko, E.; Mazzei, R.; Tadey, D.; Lombardo, D.; Nucl. Instrum. Methods Phys. Res., Sect. B 2001, 185, 204.

3. Mitchel, S. A.; Davidson, M. R.; Bradley, R. H.; J. Colloid Interface Sci. 2005, 281, 122.

4. Scotchford, C. A.; Cascone, M. G.; Downes, S.; Giusti, P.; Biomaterials 1998, 19, 1.

5. Raabe, D.; Sander, B.; Friák, M.; Ma, D.; Neugebauer, J.; Acta Mater. 2007, 55, 4475.

6. Oak, J-J.; Inoue, A.; Mater. Sci. Eng., A 2007, 449-451, 220.

7. Okazaki, Y.; Gotoh, E.; Biomaterials 2005, 26, 11.

8. Liu, Y.; Sheng, X.; Dan, X.; Xiang, Q.; Mater. Sci. Eng., C 2006, 26, 1390 .

9. Li, S. J.; Niinomi, M.; Akahori, T.; Kasuga, T.; Yang, R.; Hao, Y. L.; Biomaterials 2004, 25, 3369.

10. Cui, F-Z.; Li, Y.; Ge, J.; Mater. Sci. Eng., R 2007, 57, 1.

11. Tunney, M. M.; Jones, D. S.; Gorman, S. P.; Int. J. Pharm. 1997, $151,121$.

12. Rajaraman, R.; Rounds, D. E.; Yen, S. P. S.; Rembaum, A. A.; Exp. Cell Res. 1974, 88, 327.

13. Anselme, K.; Biomaterials 2000, 21, 667.

14. Dobkowski, J.; Kolos, R.; Jaroslawki, K.; Kowalczyñska, H. M.; J. Biomed. Mater. Res. 1999, 47, 234.

15. Webb, K.; Hlady, V.; Tresco, P. A.; J. Biomed. Mater. Res. 1998, $41,422$.

16. Daw, R.; Candan, S.; Beck, A. J.; Devlin, A. J.; Brook, I. M.; MacNeil, S.; Dawson, R. A.; Short, R. D.; Biomaterials 1998, 19, 1717.

17. Shelton, R. M.; Rasmussen, A. C.; Davies, J. E.; Biomaterials 1988, 9, 24. 
18. Van Wachem, P. B.; Hogt, A. H.; Beugeling, T.; Feijen, J.; Bantjes, A.; Detmers, J. P.; Van Aken, W. G.; Biomaterials 1987, $8,323$.

19. Bos, R.; Van der Mei, H. C.; Busscher, H. J.; FEMS Microbiol. Rev. 1999, 23, 179.

20. Tsai, I. Y.; Kimura, M.; Stockton, R.; Green, J. A.; Puig, R.; Jacobson, B.; Russell, T. P.; J. Biomed. Mater. Res., Part A 2004, $71 \mathrm{~A}, 462$.

21. Lovera, D.; Ruckdaschel, H.; Goldel, A.; Behrendt, N.; Frese, T.; Sandler, J. K. W.; Altstadt, V.; Giesa, R.; Schmidt, H-W.; Eur. Polym. J. 2007, 43, 1195.
22. Vyazovkin, S.; Dranca, I.; Thermochim. Acta 2006, 446, 140.

23. Yu, J. M.; Yu, Y-S.; Dubois, P.; Jerome, R.; Polymer 1997, 38, 2143.

24. Grohens, Y.; Prud'homme, R, E.; Schultz, J.; Macromolecules 1998, 31, 2545.

25. Yang, J.; Bei, J.; Wang, S.; Biomaterials 2002, 23, 2614.

26. Rogero, S. O.; Lugão, A. B.; Ikeda, T. I.; Cruz, A. S.; Mater. Res. 2003, 6, 317.

Received: December 29, 2008 Web Release Date: September 11, 2009 